\title{
PROPERTIES OF TEAK WOOD INFECTED BY Ceratocystis fimbriata
}

\author{
Jackeline Eliada Cichoski da Silva ${ }^{*}$, Ariany Mendes Cruz², Bárbara Luísa Corradi Pereira ${ }^{3}$, Aylson Costa \\ Oliveira $^{5}$, Waldelaine Rodrigues Hoffmann ${ }^{6}$.
}

Universidade Federal de Mato Grosso - Departamento de Engenharia Florestal, Cuiabá, Mato Grosso, Brasil - 1*jackecichoski@ gmail.com; ${ }^{2}$ arianycmendes@gmail.com ; ${ }^{3}$ babicorradi@gmail.com ; ${ }^{4}$ aylsoncosta@gmail.com ; ${ }^{5}$ waldelaine.hoffmann@gmail.com

Received for publication: 20/08/2020 - Accepted for publication: 05/01/2021

\begin{abstract}
Resumo
Propriedades da madeira de teca infectada por Ceratocystis fimbriata. O crescimento da área plantada com Tectona grandis (teca) no Brasil é acompanhado pelo aumento na incidência da murcha de Ceratocystis, doença cujo fungo coloniza o sistema vascular da árvore. O objetivo deste trabalho foi avaliar as propriedades da madeira de teca infectada por Ceratocystis fimbriata em diferentes posições radiais. Foram coletadas dez árvores com 17 anos de idade, cinco infectadas e cinco sadias. De cada árvore retirou-se um disco da base para determinação da dureza Janka, densidade básica, análise anatômica, parâmetros colorimétricos no sistema CIEL*a*b* e solubilidade em hidróxido de sódio $(\mathrm{NaOH})$. Não houve diferença significativa para posição radial e sanidade na densidade básica e dureza Janka da madeira, cujos valores médios foram de $0,488 \mathrm{~g} . \mathrm{cm}^{3} \mathrm{e}$ 58,66 MPa, respectivamente. Observou-se deposição de compostos escuros no interior das células parenquimáticas e fibras, além da formação de tilos no alburno. Houve predominância do pigmento amarelo na formação da cor da madeira de teca que foi influenciada pela posição radial, sendo o alburno mais claro. Em relação à infecção de $C$. fimbriata, a alteração de cor foi mais evidente no alburno. Já a solubilidade em $\mathrm{NaOH}$ foi menor para a madeira de alburno atacada pelo fungo. Conclui-se que as alterações na madeira de teca infectada por $C$. fimbriata são de caráter visual e não há deterioração da estrutura anatômica.

Palavras-chave: Tectona grandis, colorimetria, anatomia.
\end{abstract}

\begin{abstract}
In Brazil, the growth of Tectona grandis (teak) plantations is accompanied by an increased incidence of Ceratocystis wilt, a fungal disease that colonizes the vascular system of such tree. The objective of this work was to evaluate the properties of teak wood infected with Ceratocystis fimbriata at different radial positions. Ten 17-year-old trees (five infected and five healthy) were collected. A disk was removed from the base of each tree to determine Janka hardness, basic density, anatomical analysis, colorimetric parameters in the CIEL*a*b* system and sodium hydroxide solubility $(\mathrm{NaOH})$. There were no significant differences for radial position and health for basic density and Janka hardness of the wood, with mean values of $0.488 \mathrm{~g} . \mathrm{cm}^{3}$ and $58.66 \mathrm{MPa}$, respectively. The deposition of dark compounds was observed inside the parenchyma cells and fibers, as well as the formation of tyloses in the sapwood. Yellow pigment was predominant in the color formation of teak wood, which was influenced by radial position, with the sapwood being lighter. Regarding C. fimbriata infection, the color change was more evident in sapwood. Conversely, the $\mathrm{NaOH}$ solubility was lower for the sapwood attacked by the fungus. In conclusion, the changes in teak wood infected by $C$. fimbriata are visual and the anatomical structures do not deteriorate.
\end{abstract}

Keywords: Tectona grandis, colorimetry, anatomy.

\section{INTRODUCTION}

Fungi of the genus Ceratocystis are widely distributed geographically and cause serious diseases to various plants in tropical, subtropical and temperate climates (NASUTION et al., 2019). Ceratocystis fimbriata Ellis \& Halst, which causes Ceratocystis wilt, is cited as one of the most violent and economically important vascular pathogens in forest plantations (FERREIRA et al., 2013).

The fungus penetrates trees through injuries, directly from the roots or through injuries along the stem (FERREIRA et al., 2013). The fungus then colonizes the vascular system, which obstructs the raw sap flow and disease development is associated with wood discoloration in the form of dark spots, wilting and leaf yellowing, as well as to canker (TUMURA et al., 2012; FERREIRA et al., 2013). Thus, tree growth is significantly reduced (MAFIA et al., 2013; FERNANDES et al., 2014), and can culminate in tree death.

According to Ferreira et al. (2013), the fungus $C$. fimbriata is native to Brazil and most of its woody host species are exotic. This is true for Tectona grandis Linn F., teak, which originates from Southeast Asia and is one of the most valuable woods in the international market (ARIAS; MONTEUUIS, 2013), and was first recorded with a C. fimbriata infection by Firmino et al. (2012). In Brazil, the area of teak plantations increased $~ 30 \%$ in eight years, increasing from 65,440 hectares in 2010 to 93,957 hectares in 2018 (IBÁ, 2019), leading to an increase in the incidence and severity of Ceratocystis wilt. Additionally, since the teak wood used in products needs to meet high-quality standards, forestry treatments are needed throughout the rotation cycle since cuts and injuries caused by pruning can become fungus infection sites. 
In order to minimize the damages caused by Ceratocystis wilt and make infected wood useful, it is important to understand how the fungus acts on teak wood. Such information can be used to obtain higher quality products e.g., construction of luxurious furniture, laminates for decoration and shipbuilding due to properties such as natural resistance and good workability (ARIAS; MONTEUUIS, 2013). In addition, a striking feature of teak wood is the clear color distinction between its golden brown and shiny heartwood and light-colored sapwood.

Although there is information about how $C$. fimbriata damages forest plantations, studies about changes in the quality of infected wood are scarce (MAFIA et al., 2013; FERNANDES et al., 2014). Thus, the objective of this work was to evaluate the properties of teak wood infected by $C$. fimbriata and in different radial positions.

\section{MATERIALS \& METHODS}

To perform this research, ten trees of $T$. grandis were selected and collected, with approximately 17 years old from a commercial plantation located in the municipality of Santo Antônio do Leverger, in Mato Grosso. Of these, five were infected with the $C$. fimbriata fungus and five were healthy. A five $\mathrm{cm}$ thick disk was removed from each tree, at a height of $\sim 50 \mathrm{~cm}$ above the ground, where the average diameter of the tree was $30 \mathrm{~cm}$.

Four quadrants were marked on each disk, starting from two perpendicular lines passing through the medulla, and each sample was prepared for analysis as shown in Figure 1.

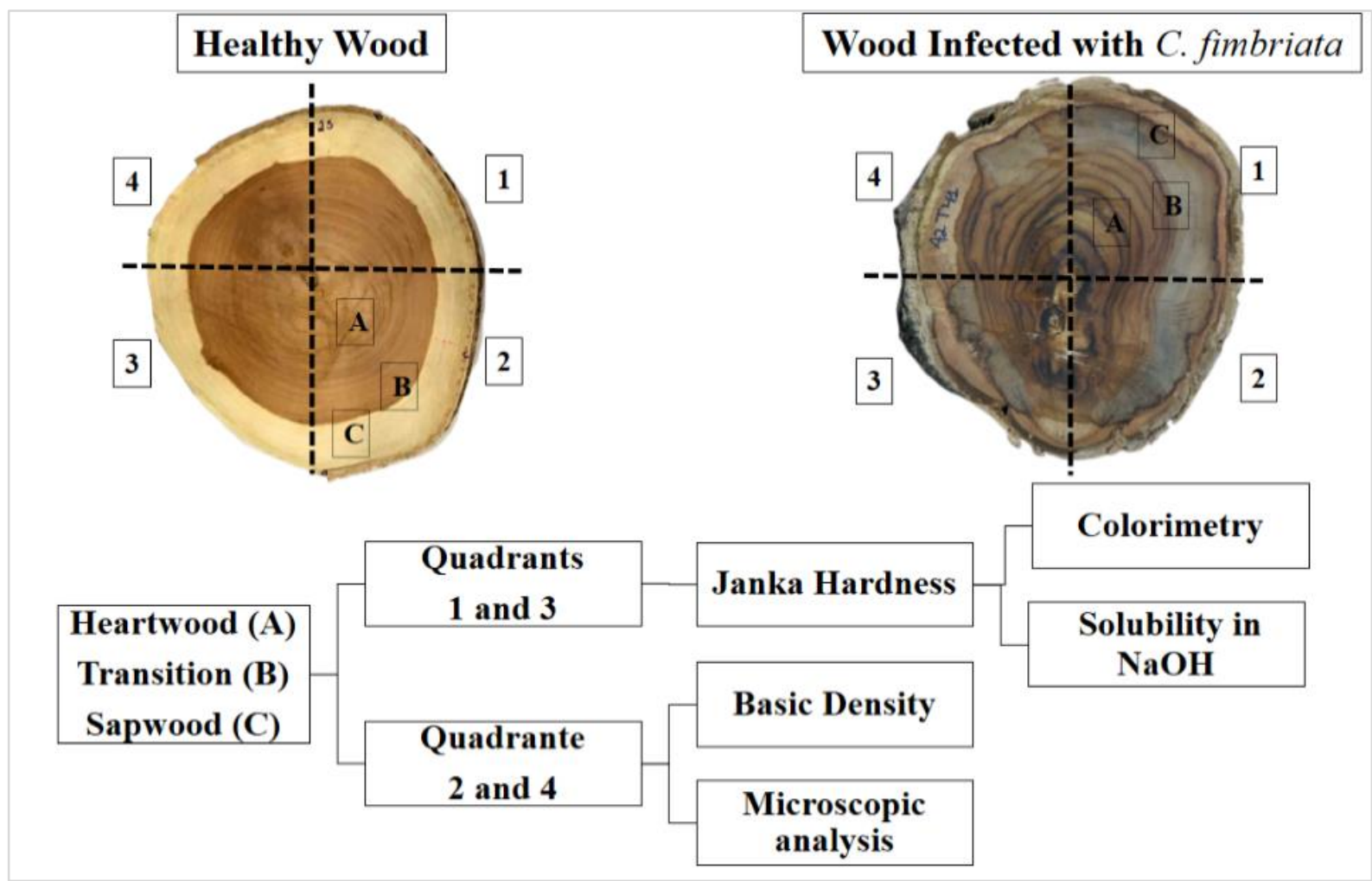

Figure 1 - Diagram of disk division of T. grandis (healthy and infected with C. fimbriata) in quadrants used to evaluate wood properties in heartwood (A) transition wood (B) and sapwood (C) regions.

Figura 1 - Esquema da divisão dos discos de T. grandis, sadios e infectados com C. fimbriata, em quadrantes para avaliação das propriedades da madeira nas regiões de cerne (A), transição (B) e alburno (C).

The Janka hardness test parallel to the fibers was performed in the central part of two opposite quadrants on the entire disk, in the heartwood (A), transition between heartwood and sapwood (B) and sapwood (C) regions, in W Lestor Universal Testing Machine Tester type AMSLER $200 \mathrm{kN}$. The Janka hardness of the wood was calculated by the relationship between the maximum force necessary to penetrate a steel semi-sphere and the diametrical section of the sphere, according to the NBR 7190 technical standard (ABNT, 1997).

After the mechanical tests, the quadrants were divided, and each was separated into sapwood, transition and heartwood regions. Wood from the two untested quadrants was used for anatomical analysis and to determine the basic wood density according to the NBR 7190 technical standard (ABNT, 1997).

To evaluate the fungus attack on a microscopic scale, histological slides of sapwood with and without $C$. fimbriata were prepared and boiled in distilled water for softening. Cuts were made in the transversal, longitudinal 
tangential and radial planes with an average thickness of $20 \mu \mathrm{m}$, using a Thermo Scientific automatic vertical slide microtome, model HM 355S. Permanent slides were made with unstained cuts and were colored with $1 \%$ safranin. The images were obtained with an optical microscope attached to a Primo Star model Zeiss digital camera.

The samples of the quadrants submitted to mechanical tests were ground in a Wiley mill and the sawdust fraction was classified and kept in the 60-mesh sieve for further analysis.

The colorimetric parameters were measured with a portable Konica Minivolta spectrophotometer, CR410 model. The colorimetric parameters $\mathrm{L}^{*}, \mathrm{a}^{*}$ and $\mathrm{b}^{*}$, were obtained based on the CIEL*a*b*(Commission International de L'Eclairage) system. The $\mathrm{L}^{*}$ coordinate represents luminosity or clarity, which ranges from zero (black) to 100 (white). $\mathrm{A}^{*}$ and $\mathrm{b}^{*}$ represent the green-red and blue-yellow chromatic coordinates, respectively, ranging from -60 and +60 . The positive and negative signs indicate the increase in tone: red $\left(+a^{*}\right)$, green $\left(-a^{*}\right)$, yellow $\left(+b^{*}\right)$ and blue $\left(-b^{*}\right)$.

Equations 1 and 2 were used to calculate parameters $\mathrm{C}$ (saturation) and $\mathrm{h} *$ (tonality angle):

$$
\begin{aligned}
& C=\sqrt{ }\left(a *^{2}+b *^{2}\right) \\
& h *=\tan ^{-1}(b * / a *)
\end{aligned}
$$

where: $a^{*}=$ green-red color coordinate; $b^{*}=$ blue-yellow color coordinate.

The color saturation (C) corresponds to the radius of the tint circle, part of the gray point of the luminosity axis until the pure spectral color and ranges from 0 to 60 . The parameter $h^{*}$ (tonality angle) originates from the green-red axis, counting positively in the trigonometric direction of rotation and indicates the mastery of a tint component in one color (PINCELLI et al., 2012).

Color variation $(\Delta \mathrm{E})$ was also calculated according to the D2244 standard (ASTM, 2016) and was classified according to Hikita et al. (2001). Subsequently, the values of the parameters $\mathrm{L}^{*}, \mathrm{a}^{*}$ and $\mathrm{b}^{*}$ were transformed into RGB (abbreviation of the additive color system formed by Red, Green, and Blue), to construct a representative figure of colorimetric characterization.

Solubility in $1 \%$ sodium hydroxide $(\mathrm{NaOH})$ was determined according to the NBR 7990 technical standard (ABNT, 2010) in duplicates. Air-dried wood samples were used and submitted to extraction in alkali solution in a boiling water bath for one hour.

The experiment followed a completely randomized design in a factorial scheme, with two health conditions (healthy and infected by Ceratocystis fimbriata), three radial positions (sapwood, transition and heartwood) and five repetitions (trees). The data was submitted to variance analysis (ANOVA), performing the respective consequences of significant interactions. The different treatments were compared by the Tukey test at $5 \%$ significance, when significant differences were found.

\section{RESULTS}

\section{Basic density, Janka hardness and anatomical structure}

There were significant interactions between the factors radial position and health for basic density and Janka hardness (p-value<0.05). Since they are independent, the factors were evaluated separately. When evaluated in isolation, the health and position factors also had no significant effect on the properties mentioned ( $\mathrm{p}$-value $<0.05$ ), as shown in Figure 2. For basic density, the mean value and standard deviation were 0.488 g.cm ${ }^{-3}$ and $0.340 \mathrm{~g} . \mathrm{cm}^{-3}$, respectively. The mean value of Janka hardness was $58.66 \mathrm{MPa}$, with a standard deviation of 6.06 $\mathrm{MPa}$.

Differences were observed between the anatomical characters of the healthy sapwood (Figures 3A-3C) and the sapwood infected by $C$. fimbriata (Figures 3D-3F and 4A-4F). These changes are related to the deposition of dark colored compounds inside parenchyma cells and fibers, mainly the radial parenchyma, in addition to vessel obstruction. However, the anatomical structure remained unchanged, i.e., microscopic analysis did not indicate cell wall deterioration. 

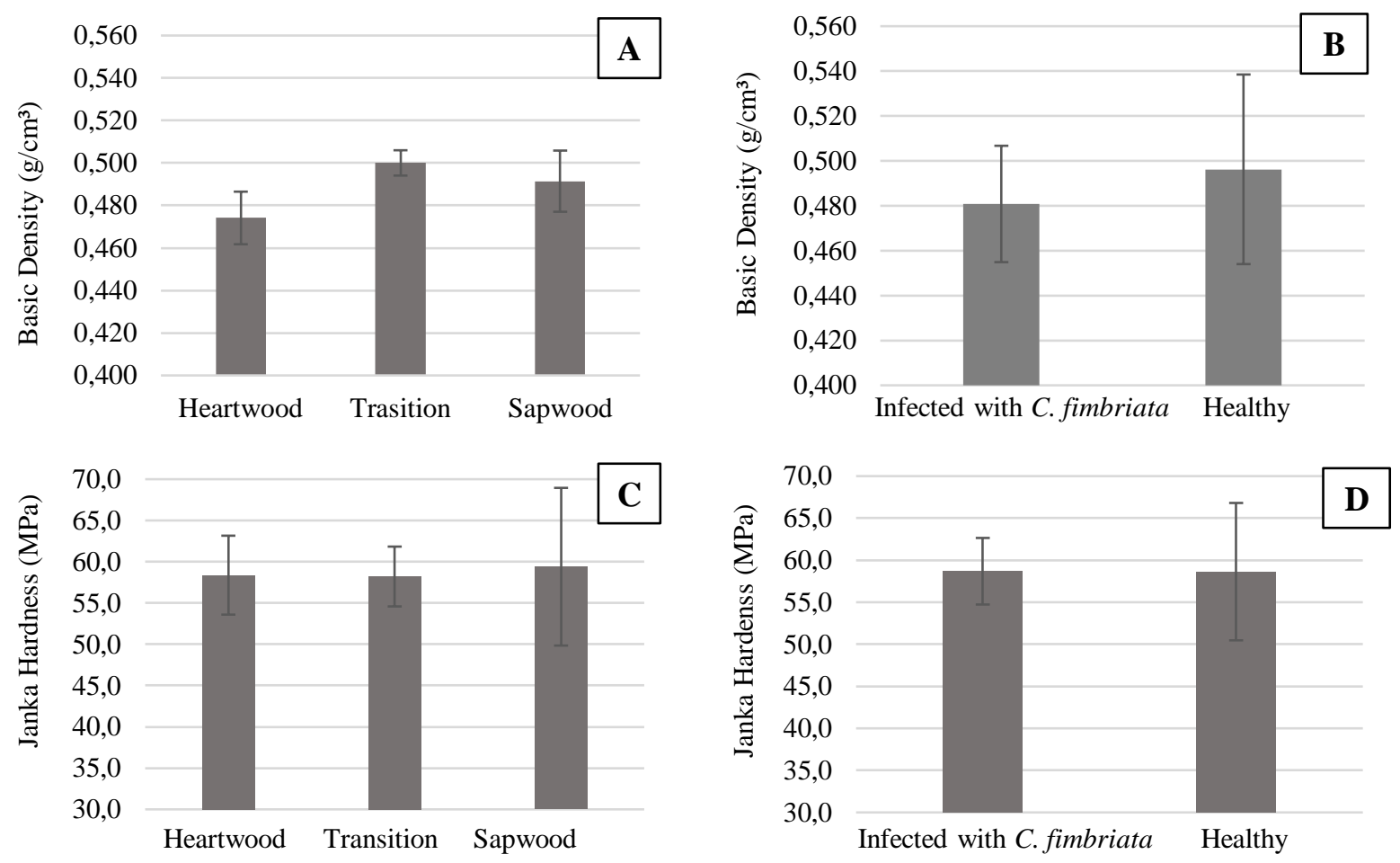

Figure 2 - Mean values and standard deviation of: basic density of teak wood in (A) different radial positions and in (B) different health conditions; Janka hardness of the wood in (C) different radial positions and in (D) different health conditions.

Figura 2 - Valores médios e desvio padrão de: densidade básica da madeira de teca em (A) diferentes posições radiais e em (B) diferentes condições de sanidade; dureza Janka da madeira em (C) diferentes posições radiais e em (D) diferentes condições de sanidade.
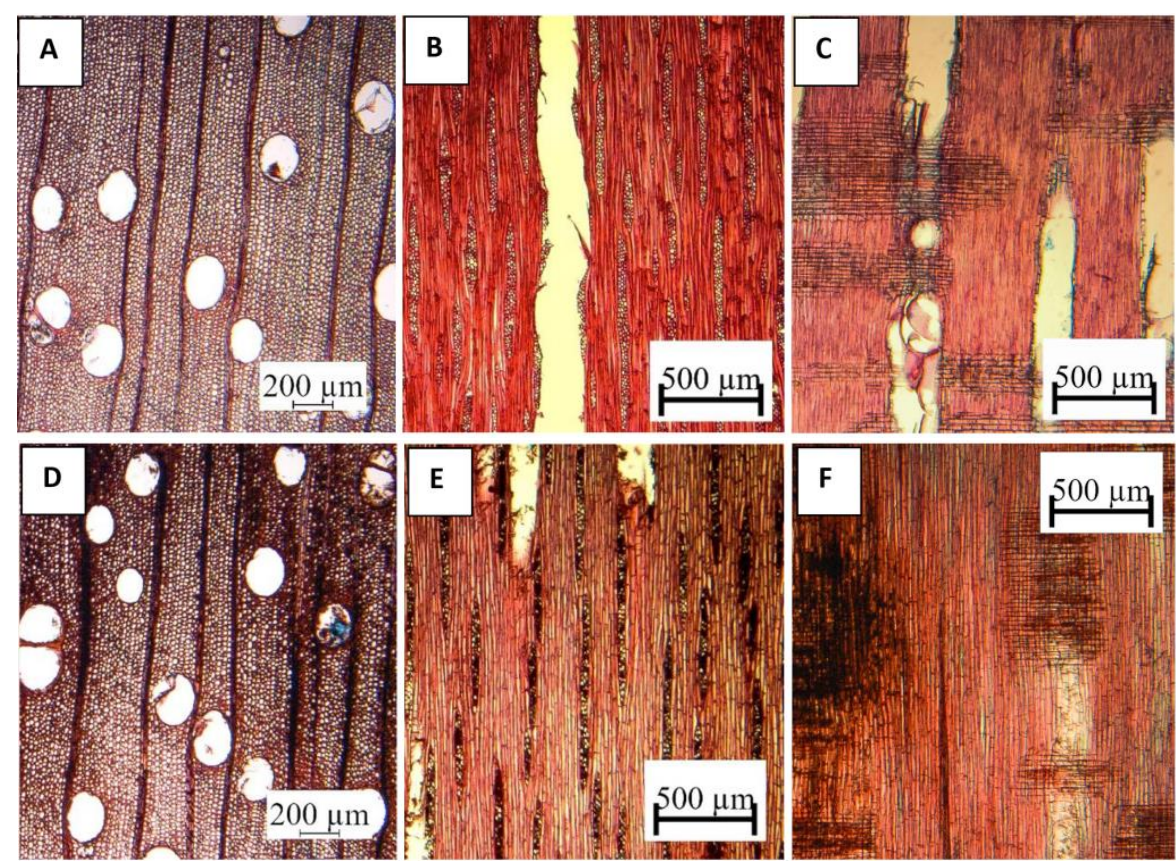

Figure 3 - Micrographs of healthy T. grandis sapwood: transverse (A), tangential (B) and radial (C) sections. T. grandis wood with incidence of $C$. fimbriata: transversal (D), tangential (E) and radial (F)sections.

Figura 3 - Micrografias de madeira de alburno de T. grandis sadia: seções transversal (A), longitudinal tangencial (B) e longitudinal radial (C). Madeira de T. grandis com incidência de C. fimbriata: seções transversal (D), longitudinal tangencial (E) e longitudinal radial (F). 


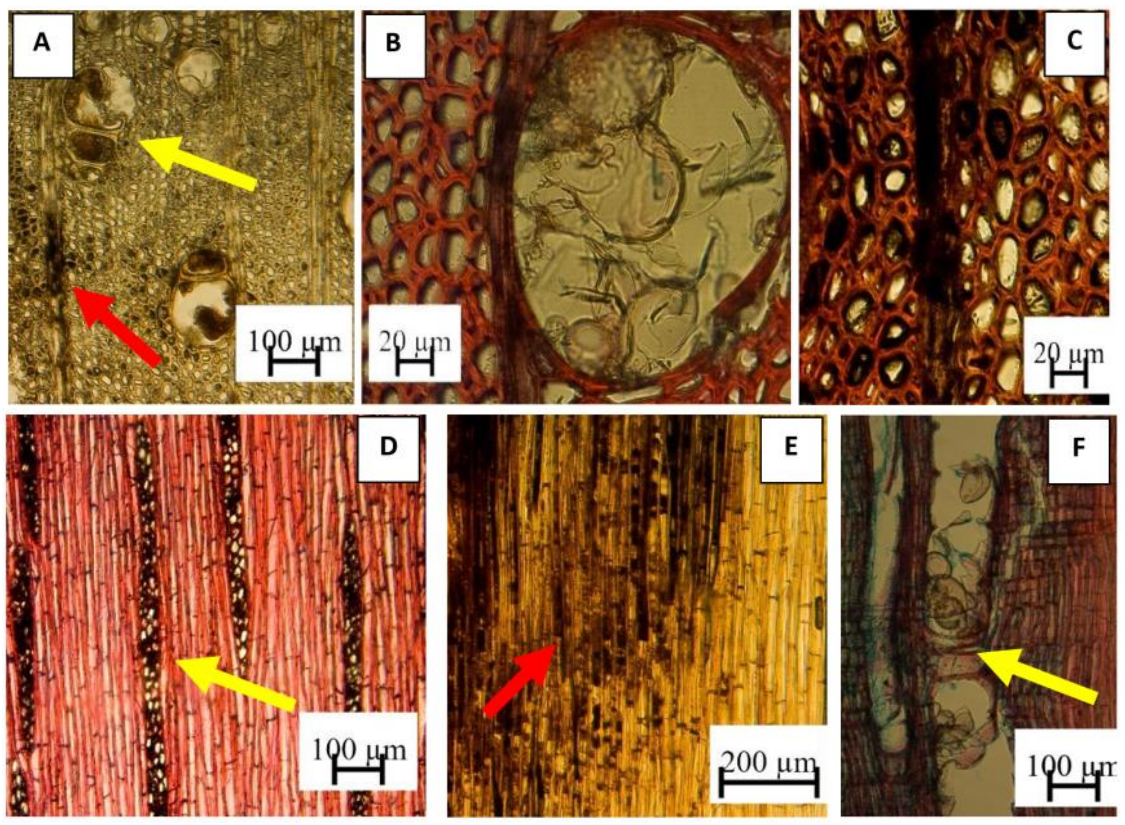

Figure 4 - Details of the infected cross-section: (A) deposition of dark substance in cells (red arrow) and blocked pores (yellow arrow); (B) blocked pore; (C) deposition of dark substance inside the fibers and radial parenchyma. (D) Details of the tangential section, with deposition of dark substance in the radial parenchyma and radial section: (E) deposition of dark substance on the fibers; (F) blocked vessel.

Figura 4 - Detalhes da seção transversal infectada: (A) deposição de substância escura nas células (seta vermelha) e poros obstruídos (seta amarela); (B) poro obstruído; (C) deposição de substância escura no interior das fibras e parênquima radial. (D) Detalhes da seção tangencial, com deposição de substância escura no parênquima radial e da seção radial: (E) deposição de substância escura nas fibras; (F) vaso obstruído.

\section{Colorimetric parameters and solubility in $\mathrm{NaOH}$}

For colorimetric parameters, there were significant interactions between the factors position and health for $\mathrm{L}^{*}, \mathrm{C}$ and $\mathrm{b}^{*}($ Table 1$)$.

Table 1 - Average values of the colorimetric parameters: L* (luminosity), C (saturation) and b (blue-yellow chromatic coordinate)

Tabela 1 - Valores médios dos parâmetros colorimétricos: L* (luminosidade), C (saturação) e b* (coordenada cromática azul-amarelo)

\begin{tabular}{|c|c|c|c|}
\hline \multirow{2}{*}{ Parameter } & \multirow{2}{*}{ Radial position } & \multicolumn{2}{|c|}{ Health Condition } \\
\hline & & Healthy & Infected with $C$. fimbriata \\
\hline \multirow{3}{*}{$\mathbf{L}^{*}$} & Sapwood & $70,01^{(0,87)}$ Aa & $59,43^{(2,63)} \mathrm{Ba}$ \\
\hline & Transition & $50,95^{(2,78)} \mathrm{Ab}$ & $47,51^{(0,35)} \mathrm{Bb}$ \\
\hline & Heartwood & $52,17^{(1,84)} \mathrm{Ab}$ & $50,02^{(1,12)} \mathrm{Ab}$ \\
\hline \multirow{3}{*}{$\mathbf{C}$} & Sapwood & $23,84^{(0,89)} \mathrm{Aa}$ & $15,27^{(2,38)} \mathrm{Ba}$ \\
\hline & Transition & $18,33^{(1,49)} \mathrm{Ab}$ & $16,35^{(0,68)} \mathrm{Aa}$ \\
\hline & Heartwood & $19,11^{(1,39)} \mathrm{Ab}$ & $17,74^{(0,93)} \mathrm{Aa}$ \\
\hline \multirow{3}{*}{$\mathbf{b}^{*}$} & Sapwood & $23,31^{(0,90)} \mathrm{Aa}$ & $14,58^{(2,32)} \mathrm{Ba}$ \\
\hline & Transition & $16,90^{(1,61)} \mathrm{Ab}$ & $14,88^{(0,71)} \mathrm{Aa}$ \\
\hline & Heartwood & $17,72^{(1,37)} \mathrm{Ab}$ & $16,44^{(1,03)} \mathrm{Aa}$ \\
\hline
\end{tabular}

For the same parameter, the same uppercase letters in the row and lowercase ones in the column do not differ from each other by the Tukey test at $5 \%$ significance. 
The healthy sapwood was $17.8 \%$ lighter (higher L value), $56.1 \%$ more saturated (higher C value) and $59.9 \%$ more yellow pigment (higher $\mathrm{b}^{*}$ value) compared to sapwood infected by $C$. fimbriata. However, for heartwood and transition, the parameters L, C and $b^{*}$ were statistically equal (p-value<0.05) in both health conditions, except for the $\mathrm{L}$ parameter in the transition region. This shows that the incidence of the fungus did not alter the parameters mentioned in the heartwood and transition regions. In relation to the healthy wood, the sapwood presented higher values of $\mathrm{L}, \mathrm{C}$ and $\mathrm{b}^{*}$, when compared to the heartwood and transition regions. For wood infected by $C$. fimbriata, only the luminosity of the sapwood was statistically higher than the other regions.

For colorimetric parameters $\mathrm{a}^{*}$ and $\mathrm{h}$, no significant interactions were found between radial position and health and the factors were analyzed separately (Table 2).

Table 2 - Mean values of colorimetric parameters: a * (green-red chromatic coordinate) and $\mathrm{h} *$ (tonality angle) Tabela 2 - Valores médios dos parâmetros colorimétricos: a* (coordenada cromática verde-vermelho) e h* (ângulo de tonalidade)

\begin{tabular}{ccc|ccc}
\hline \multirow{2}{*}{ Parameter } & \multicolumn{2}{c|}{ Health Condition } & \multicolumn{2}{c}{ Posição radial } \\
\cline { 2 - 6 } & Healthy & $\begin{array}{c}\text { Infection with } \\
\text { C. fimbriata }\end{array}$ & Sapwood & Transition & Heartwood \\
\hline $\mathbf{a}^{*}$ & $5,96^{(1,08)} \mathrm{a}$ & $6,41^{(1,27)} \mathrm{a}$ & $4,73^{(0,78)} \mathrm{B}$ & $6,92^{(0,29)} \mathrm{A}$ & $6,90^{(0,36)} \mathrm{A}$ \\
\hline $\mathbf{h}^{*}$ & $71,03^{(5,27)} \mathrm{a}$ & $68,80^{(3,92)} \mathrm{b}$ & $75,43^{(3,61)} \mathrm{A}$ & $66,37^{(1,78)} \mathrm{B}$ & $67,94^{(1,06)} \mathrm{B}$ \\
\hline
\end{tabular}

The same letters in each line within the same factor (lowercase for health condition and uppercase to position) do not differ from each other by the Tukey test at $5 \%$ significance.

C. fimbriata infectiondidnot change the amount of red pigment $\left(\mathrm{a}^{*}\right)$ in teak wood, regardless of radial position. Regarding the positions, sapwood presented $31 \%$ less red pigment compared to the transition and heartwood. The tonality angle $\left(\mathrm{h}^{*}\right)$ was statistically higher for the healthy wood and the sapwood region when the factors health and position were assessed independently.

Table 3 shows the color representation, the numerical color variations $(\Delta \mathrm{E})$, caused by the $C$. fimbriata infection, as well as thevisual classification of color variation.

Table 3 - Visual and numerical representation of the color variation $(\Delta \mathrm{E})$ of radial positions with and without $C$. fimbriata infection

Tabela 3 - Representação visual e numérica da variação de cor $(\Delta \mathrm{E})$ das posições radiais com e sem incidência de C. fimbriata

\begin{tabular}{cccc}
\hline Wood & Sapwood & Transition & Heartwood \\
\hline Healthy & & & \\
\hline $\begin{array}{c}\text { Infected with } \boldsymbol{C} \text {. } \\
\text { fimbriata }\end{array}$ & 14,02 & 4,12 & 2,93 \\
\hline $\boldsymbol{\Delta E}$ & Very appreciable & Appreciable & Notable \\
\hline $\begin{array}{c}\text { Classification } \\
(\text { Hikita } \text { et al., 2001) }\end{array}$ & & & \\
\hline$\Delta \mathrm{E}$ : Color variation. & & & \\
\hline
\end{tabular}

For the solubility in $\mathrm{NaOH}$ of the teak wood, there was significant interaction between the factors health and radial position, i.e., the variables were dependent (Table 4). The sapwood infected by $C$. fimbriata presented significantly lower solubility in $\mathrm{NaOH}$ when compared to healthy sapwood, when assessing the health factor and at the heartwood and the transition with incidence of $C$. fimbriata, when comparing the wood regions. 
Table 4 - Mean values and standard deviation of $\mathrm{NaOH}$ soluble substances as a function of health and radial positions in $T$. grandis wood

Tabela 4 - Valores médios e desvio padrão das substâncias solúveis em $\mathrm{NaOH}$ em função da sanidade e das posições radiais na madeira de $T$. grandis

\begin{tabular}{ccc}
\hline \multirow{2}{*}{ Radial position } & \multicolumn{2}{c}{ Health Condition } \\
\cline { 2 - 3 } Sapwood & Healthy & Infected with $C$. fimbriata \\
\hline Transition & $20,98^{(0,97)} \mathrm{Aa}$ & $17,62^{(1,41)} \mathrm{Bb}$ \\
\hline Heartwood & $21,00^{(0,64)} \mathrm{Aa}$ & $20,69^{(0,38)} \mathrm{Aa}$ \\
\hline & $22,30^{(0,84)} \mathrm{Aa}$ & $21,24^{(0,98)} \mathrm{Aa}$ \\
\hline
\end{tabular}

Averages followed by the same letter, uppercase for health condition (row) and lowercase for position (column), do not differ from each other according to the Tukey test at $5 \%$ significance.

\section{DISCUSSION}

\section{Basic density, Janka hardness and anatomical structure}

C. fimbriata infection did not significantly (p-value<0.05) affect the basic density and Janka hardness of teak wood. Fungi of the genus Ceratocystis are classified as staining fungi (CARVALHO et al., 2018), therefore they do not degrade the cell wall of the fibers and the physical-mechanical properties of wood with this type of fungus do not change significantly. Fernandes et al. (2014) also found no significant variation in basic density for eucalyptus wood with $C$. fimbriata, while Mafia et al. (2013) found an 8\% reduction in basic density for eucalyptus wood attacked by the fungus. Herein, a $3 \%$ decrease in the mean basic density was found for teak wood infected by $C$. fimbriata when compared to healthy wood (Figure 2).

The low variation of the basic density in the radial direction, regardless of the health condition, indicates that the evaluated wood had homogeneous characteristics. According to Bonduelle et al. (2015), who evaluated 18 -year-old teak wood, this is interesting because the other properties, especially mechanical ones, are densitydependent and should not present marked variation, as was found for Janka hardness herein (Figure 2).

The results found herein are consistent with those that have been reported in the literature. Chagas et al. (2014) found a basic density of $0.518 \mathrm{~g} . \mathrm{cm}^{-3}$ for teak wood from a 12-year-old plantation in Mato Grosso and Dias et al. (2018) found $0.510 \mathrm{~g} . \mathrm{cm}^{-3}$ for 13-year-old teak wood from Minas Gerais. Regarding Janka hardness, Flórez et al. (2014) found an average value of $46.58 \mathrm{MPa}$ for teak from a 13-year-old plantation in Minas Gerais. Considering the mean values of basic density and Janka hardness, the wood studied was classified as moderately heavy and moderately hard, according to the Forest Products Laboratory classification table (1973).

A common symptom of $C$. fimbriata infection is dark radial striae that can be observed microscopically in the wood's cross section (Figures 3D, 4A). Discoloration, i.e., the change in the natural color of wood, is a consequence of $C$. fimbriata attacking the living cells of the parenchyma (FERREIRA et al., 2013; NASUTION et al., 2019), as observed when comparing Figures 3A, 3B and 3C with 3D, 4E and 3F, respectively. Staining fungi are nourished by carbohydrates contained in the cytoplasm(CARVALHO et al.,2018) and the darkening of colonized tissues is the result of changes in the cellular content of radial parenchyma cells, through oxidation and polymerization processes of phenolic compounds (TUMURA et al., 2012).

The tyloses from Figures $4 \mathrm{~A}, 4 \mathrm{~B}$ and $4 \mathrm{~F}$ are formed by the contents of parenchyma cells adjacent to the vessels that penetrate the vessels through the points and form a set of globular proliferations. The formation of tyloses inside the sapwood vessels is a common response to xylem colonization by pathogens (PARK et al., 2013). According to the same authors, tyloses are considered a primary defense mechanism against vascular attacks, as they help interrupt the transport of pathogens in the xylem vessels.

However, the tyloses prevent the normal flow of the raw sap, and consequently, leaves start to wilt since the water absorbed by the root system does not adequately supply the aerial part of the plant (TUMURA et al., 2012). Thus, there is a decrease in the volumetric production of wood or even tree death (MAFIA et al., 2013; FERNANDES et al., 2014). When considering the use of this wood, the presence of tyloses decreases permeability, negatively affecting drying and impregnation processes with some type of solution.

No damages to the cell wall of fibers or vessels were observed (Figures 3A, 4B, 4C, 4D, 4E), which classifies $C$. fimbriata as a staining fungus, as observed by Mafia et al. (2013). When evaluating eucalyptus wood infected by $C$. fimbriata through scanning electron microscopy, Mafia et al. observed the presence of hyphae growth through vessel scores. The lack of deterioration to the anatomical structure indicates that $C$. fimbriata infection does not structurally damage wood but damages it aesthetically. 


\section{Colorimetric parameters and solubility in $\mathrm{NaOH}$}

Higher values of the L parameter for sapwood and lower values for transition and heartwood (Table 1) are explained by tree growth. As the internal parts move away from the exchange rate and the parenchyma cells lose their vital activity, the wood becomes darker due to the deposition of substances resulting from the chemical transformation of the reserve materials (BURGER; RICHTER, 1991). In wood infected with Ceratocystis, darkening is attributed to the deposition of a set of polymerized chemicals as a response to fungus attack and also by the pigmentation of spores and hyphae (NASUTION et al., 2019), as shown in Figures 3and 4.

According to the classification proposed by Camargos and Gonçalez (2001), transition and heartwood, regardless of the state of health, are classified as dark $(\mathrm{L}<56)$ and sapwood, with or without $C$. fimbriata, is considered clear ( $\mathrm{L}>56)$. According to the same classification, all woods can be considered color woods with low saturation because they have values lower than 30, i.e., they have grayer in their color compositions.

As the coordinate $b^{*}$ (Table 1) presented higher values in relation to $a^{*}$ (Table 2), there was a predominance of yellow tint in the color formation of teak wood for all radial positions evaluated, as well as for health conditions. The tonality angle $\left(\mathrm{h}^{*}\right)$ greater than $65^{\circ}$ (Table 2 ) confirms the proximity of the colors of teak wood to the yellow axis, whether from heartwood, sapwood or transition and with or without $C$. fimbriata. The average values of $L, a^{*}$ and $b^{*}$ of the healthy wood are close to those verified by Garcia and Marinonio (2016), when evaluating teak heartwood and sapwood.

Table 3 highlights the color change $(\Delta \mathrm{E})$ of teak wood caused by $C$. fimbriata infection, emphasizing the color change of the sapwood, although it is noticeable in the other wood regions, as observed in Figure 1. The color of the sapwood went from white to grayish pink and the transition and heartwood regions remained classified as olive and dark brown, respectively, according to the classification of Camargos and Gonçalez (2001). Such color change is the main damage caused by wood-staining fungi, which has implications for the aesthetic and commercial value of the material (CARVALHO et al., 2018). Furthermore, these authors highlight that since hyphae can penetrate deep into the wood, stains cannot be removed with a sander or planer.

According to Carvalho et al. (2018), the percentage of stained wood allowed for structural use in outdoor environments is a maximum of $25 \%$, while for indoor use there is no limit. However, the use of wood infected with Ceratocystis poses a threat to biosafety in places where the fungi are not yet present (NASUTION et al., 2019), as contaminated wood could spread the pathogen through the export of wood products.

For the content of substances soluble in $\mathrm{NaOH}$, these were similar in the transition and core regions and in the sapwood, the wood infected with $C$. fimbriata presented lower values. This is due to the action of Ceratocystis fungi in the living part of the tree (NASUTION et al., 2019), since staining fungi do not have enzymatic complexes that degrade wood polymers and only feed on substances that are easily assimilated, such as starches and simple sugars, present mainly in the cytoplasm of parenchyma cells (CARVALHO et al., 2018).

It is possible that the fungus fedon substances in the sapwood region, which decreased the soluble compounds in alkali solution. Extraction by sodium hydroxide is known to remove extractives and carbohydrates of low molecular mass (ABNT, 2010). Additionally, the solubility in $\mathrm{NaOH}$ may indicate the degree of wood decomposition caused by fungi and, therefore, it can be affirmed that infection by $C$. fimbriata did not degrade cell wall components, since higher solubility values were not observed in $\mathrm{NaOH}$ for the injured wood.

\section{CONCLUSION}

- The basic density and hardness of teak wood were not influenced by C. fimbriata infection and radial positions.

- Regarding the wood anatomy, the presence of $C$. fimbriata caused the deposition of dark substances in the cells and formation of tyloses in the sapwood, without deteriorating the cell wall.

- There was a predominance of yellow pigment in the color formation of teak wood and the radial position influenced the color of the wood, with sapwood being lighter. Regarding C. fimbriata infection, color change was more evident in sapwood.

- The extractive content in alcohol was not influenced by $C$. fimbriata infection and the sapwood presented lower levels. Conversely, solubility in $\mathrm{NaOH}$ was lower for the sapwood attacked by the fungus.

\section{REFERENCES}

AMERICAN SOCIETY TESTING MATERIALS. ASTM D2244: Standard practice for calculation of color tolerances and color differences from instrumentally measured color coordinates. West Conshohocken, PA, EUA: ASTM, 2016.

ARIAS, L. A. U.; MONTEUUIS, O. Teak: new trends in silviculture, commercialization and wood utilization. Catargo, C.R: International Forestry an Agroforestry, 2013, 552p. 
ASSOCIAÇÃO BRASILEIRA DE NORMAS TÉCNICAS. NBR 7190: Projeto de estruturas de madeira. Rio de Janeiro, RJ, 1997.

ASSOCIAÇÃO BRASILEIRA DE NORMAS TÉCNICAS. NBR 7990: Madeira - Determinação do material solúvel em hidróxido de sódio a 1\%. Rio de Janeiro, RJ, 2010.

BONDUELLE, G. M.; IWAKIRI, S.; TRIANOSKI, R.; PRATA, J. G.; ROCHA, V. Y. Análise da massa específica e da retratibilidade da madeira de Tectona grandis nos sentidos axial e radial do tronco. Floresta,Curitiba - PR, v. 45, n. 4, p. 671-680 2015.

BURGER, L. M.; RICHTER, H. R. Anatomia da Madeira. São Paulo: Nobel, 1. ed. 1991, 152p.

CAMARGOS, J. A. A.; GONÇALEZ, J. C. A colorimetria aplicada como instrumento na elaboração de uma tabela de cores de madeira. Brasil Florestal, Brasília - DF, n. 71, p. 30-41, 2001.

CARVALHO, D. E.; SOUZA, G. O.; BROCHINI, G. G.; GUIMARÃES, P. P.; AZAMBUJA, R. R.; ROSA, T. S.; CASTRO, V. G. Fungos manchadores e emboloradores. In: CASTRO, V. G. E GuimarÃES, P. P. (Eds.). Deterioração e Preservação da Madeira. 1 ed. Mossoró, RN: Edufersa, 2018. p. 21-40.

CHAGAS, S. F.; EVANGELISTA, W. V.; DE CASTRO SILVA, J.; CARVALHO, A. M. M. L. Propriedades da madeira de teca de diferentes idades e oriundas de desbaste. Revista Ciência da Madeira, Pelotas - RS, v. 5, n. 2, p. 138-150, 2014.

DIAS, A. C. C.; MARCHESAN, R.; ALMEIDA, V. C.; MONTEIRO, T. C.; MORAES, C. B. D. Relação entre a densidade básica e as retrações em madeira de teca. Revista Ciência da Madeira, Pelotas - RS, v. 9, n. 1, p. 3744, 2018.

FERNANDES, B. V.; ZANUNCIO, A. J. V.; FURTADO, E. L.; ANDRADE, H. B. Damage and Loss Due to Ceratocystis fimbriata in Eucalyptus Wood for Charcoal Production. Bioresources, São Paulo - SP, v. 9, n. 3, p. 5473-5479, 2014.

FERREIRA, M. A.; ALFENAS, A. C.; MAFIA, R. G. Ceratocystis fimbriata em espécies florestais e agronômicas no Brasil. In. Patologia florestal: Desafios e perspectivas. 1 ed. Lavras, MG: NEFIT, v. 1, p. 75-101, 2013.

FIRMINO, A. C.; TOZZE JR, H. J.; FURTADO, E. L. First report of Ceratocystis fimbriata causing wilt in Tectona grandis in Brazil. New Disease Reports, Grã-Bretanha, v. 25, n. 24, p. 1-1, 2012.

FLÓREZ, J. B.; TRUGILHO, P. F.; LIMA, J. T.; HEIN, P. R. G.; SILVA, J. R. M. D. Caracterización de la madera joven de Tectona grandis L. f. plantada en Brasil. Madera y bosques, México, v. 20, p. 11-20, 2014.

FOREST PRODUCTS LABORATORY. FPL-0171 Standard terms for describing wood. U.S. Department of Agriculture. Madison, USA. 1973

GARCIA, R. A.; MARINONIO, G. B. Variação da cor da madeira de teca em função da densidade e do teor de extrativos. Floresta e Ambiente, Rio de Janeiro - RJ, v. 23, n. 1, p. 124-134, 2016.

HIKITA, Y.; TOYODA, T.; AZUMA, M. Weathering testing of timber: discoloration. In: IMAMURA, Y. (Ed.). High performance utilization of wood for outdoor uses. 1 ed. Kyoto, Japão: Press-net, 2001. p. 27-32.

INDUSTRIA BRASILEIRA DE ÁRVORES (IBÁ). Brazilian Tree Industry Report. Brazilian Tree Industry. Brasília, p.80. 2019.

MAFIA, R. G.; FERREIRA, M. A.; ZAUZA, E. A. V.; SILVA, J. F.; COLODETTE, J. L.; ALFENAS, A. C. Impact of Ceratocystis wilt on eucalyptus tree growth and cellulose pulp yield. Forest Pathology, New York v. 43, n. 5, p. 379-385, 2013.

NASUTION, A.; GLEN, M.; BEADLE, C.; MOHAMMED, C. Ceratocystis wilt and canker - a disease that compromises the growing of commercial Acacia-based plantations in the tropics. Australian Forestry, Australia, v. 82, n. sup1, p. 80-93, 2019.

PARK, J.-H.; JUZWIK, J.; CAVENDER-BARES, J. Multiple Ceratocystis smalleyi Infections Associated with Reduced Stem Water Transport in Bitternut Hickory. Ecology and Epidemiology, Florida - EUA, v. 103, n. 6, p. 565-574, 2013.

PINCELLI, A. L. P. S. M.; MOURA, L. F.; BRITO, J. O. Effect of thermal rectification on colors of Eucalyptus saligna and Pinus caribaea woods. Maderas, Ciencia y tecnologia, Chile, v. 14, n. 2, p. 239-248, 2012.

TUMURA, K. G.; DE PIERI, C.; FURTADO, E. L. Murcha por Ceratocystis em eucalipto: avaliação de resistência e análise epidemiológica. Summa Phytopathologica, Botucatu - SP ,v. 38, p. 54-60, 2012. 